\title{
SPEECH ACTS ANALYSIS ON TEACHING AND LEARNING PROCESS USED BY THE TEACHER IN MAN 2 MATARAM IN ACADEMIC YEAR 2016/2017

\author{
(1) Yulia Isnaini ${ }^{(2)}$ Hurniatun
}

${ }^{(1)}$ Lecturer of English Department Muhammadiyah University of Mataram

${ }^{(2)}$ Students of English Department Muhammadiyah University of Mataram

\begin{abstract}
This study was aimed at finding out Speech Acts Analysis on Teaching and Learning Process used by the Teacher in MAN 2 Mataram in Academic year 2016/2017. The method of this research is qualitative research The data of this research were the utterances performed by the Teachers of MAN 2 Mataram. From The research instrument was the researcher himself. Participant is the subject from which the data obtained (Arikunto, 2010: 172)The Researcher's participant actively classification speech act by the Teachers on teaching and learning process . The instrument of data by using video camera and observation. To analyze the data Based on Louis (2005:181). This study was use observation and video recording as instrument of data collection, the researcher applied coding system. In this research, there are two validity principles applied by the researcher. The results of the research show that there are three classification of speech act performed by the Teachers in teaching learning process. The results of the research show that there are three classification of speech act performed by the Teachers in teaching and learning process. they are 4 data of locutionary act, 30 data of Illucotionary act, 7 data of Perlocutionary act. So the total of data were 41 data of speech act are used By the Teachers in MAN 2 Mataram.
\end{abstract}

Keywords: Speech Act ,Teaching Learning Process.

\section{Introduction}

Pragmatics concerns itself with how people use language within a context and why they use language in particular ways. This unit examines how speaker and hearer affect the ways in which language is used to perform various function." Austin in Fasold (2006: 162) points out that when people use language, they are performing a kind of action that is called speech acts. The use of the term speech act covers 'actions' such as requesting, commanding, questioning, and informing. In studying pragmatics, we concern on how to utter a speech so that the listener can interpret the meaning that is conveyed by the speaker. Speech act is an utterance that serves a function in communication. We perform speech act when we offer an apology, greeting, request, complaint, invitation, compliment, or refusal. According to Searle in Yule (1996: 47), speech act is the actions performed via utterances. Yule (1996:47) proposes that speech acts is performed action via utterance. Another definition from Crystal in Soekemi (1995:121) mentions that speech act is a theory which analyses the role of utterance in relation to the behavior of speaker and listener in interpersonal communication. The purpose of the study is to Analyze the classification of speech act that the Teacher on Teaching and Learning process in classroom in MAN 2 Mataram 2016/2017 


\section{Literature Review}

Pragmatic is the study of the aspects of meaning and language use that are dependent on the speaker, People use language in order to communicate with other people around the world. The component of language is studied in a science called linguistics. It deals with all internal and external aspects of language. For instance, sounds are discussed in phonetics and phonology, morphemes and words in morphology, phrases and sentences in syntax, meanings in semantics, and text in discourse.

Pragmatics itself is a branch of linguistics covering meaning in use. Meaning is formally studied in semantics. However, there are some aspects of meaning cannot be captured by semantics particularly meaning in use or meaning in context. It is because semantics deals with meaning without reference to the users and communicative functions of sentences (Aitchison, 2003: 104). Pragmatic forms of meaning are of utmost importance not only in linguistic and communication, but also in current theories of knowledge representation, conceptual graphs in computer cognitive sciences, as well as in the upcoming vision of a semantic web (Pietarinen, 2005;1767)

Pragmatics, therefore, is concerned with the way of speaker using language in context which cannot be predicted from purely linguistic knowledge, particularly semantics, which deals with the internal structure of the language (Griffiths, 2006: 153). Similarly, Kreidler (2002:18) explains the differences between semantics and pragmatics. According to him, both semantics and pragmatics are related to the human ability to use language in meaningful way. The difference is that semantics deals with the speaker's competence in producing meaningful utterance, while pragmatics the person's ability to interpret meanings from particular kind of speech situations (context). However, Kreidler adds that nowadays the boundary between semantics and pragmatic is very often overlapped.

Other definition of pragmatics is proposed by Yule (1996: 4). In his explanation of the differences among syntax, semantics, and pragmatics, he defines pragmatics as the study of relationship between linguistic form and the user of those forms. The user of the linguistic forms, that is human being, is the characteristic which makes pragmatics different from syntax and semantics. The role of the language user leads the scope of pragmatics to the context of the language itself (Cutting, 2002: 1).

The study of pragmatics covers several subfields or domains, such as deixis, reference, presupposition, implicature, and speech acts. Deixis is concerned with the referring expressions which indicate the location of the referents along certain dimensions. Reference deals with the linguistic forms used by the speaker to enable the listener to identify something. Presupposition is related to the things that the speaker assumes as the case of an utterance. Implicature is associated with the existence of norms for the use language in context. Speech acts are concerned with the use of utterance to perform an act. (Griffiths, 2006)

From all parts of pragmatic, the researcher was specifically discuss about speech act, that is about the three classification of speech act used by the Teacher on teaching learning process in XI Bahasa and IIS in MAN 2 Mataram in academic year 2016. 
Speech act is an utterance that serves a function in communication. We perform speech act when we offer an apology, greeting, request, complaint, invitation, compliment, or refusal. According to Searle in Yule (1996: 47), speech act is the actions performed via utterances. Yule (1996:47) proposes that speech acts is performed action via utterance. Another definition from Crystal in Soekemi (1995:121) mentions that speech act is a theory which analyses the role of utterance in relation to the behavior of speaker and listener in interpersonal communication.

Austin defines speech acts simply as the action performed by saying something. By means of utterances, ones are able to get others to do something. In other words, speech acts are actions which are performed via utterances (Yule, 1996: 48).

Speech acts reveal the intentions of speakers and the effects the speaker's utterances and expressions have on the hearers. The implication of speech acts is that every utterance has a purpose which derives from the specific context. It has been observed that language use depends on such contextual factors as social and physicalnconditions, attitudes, abilities, beliefs and the relationship existing between the speaker and the listener and a promise. While a constative utterance is one which makes an assertion (it is often the utterance of a declarative sentence) but it is not a performative.

Praising and criticizing classified as expressive speech acts. commissive speech act is a speech act that binds speakers to carry out the things mentioned in the speech. Promise or swear included in the speech act commissive. Declarative speech act is a speech act is done primarily to the intention of creating a new state. Cancel the permit including speech acts and declarations. Topics this analysis is the analysis of forms of speech acts (speech act) based on the context.

\section{Research Design}

In this Research researcher design was qualitative research Based on Louis (2005:181). The method used by the researcher applied descriptive qualitative method. It was because the data to be investigated were the utterances of Teacher on teaching learning process in MAN 2 Mataram. This study used by observation and video recording as instrument of data collection.

\section{Research Participant}

Participant is the subject from which the data obtained (Arikunto, 2010: 172). It consisted of two Teachers on one mount they are Mr. Indra speech act on teaching and learning process in class 11 Bahasa and Mrs.Asry speech act on teaching learning process in class 11 IIS.

\section{Instrument of Data Collection}

According Arikunto (2000: 134), the data collection instruments are the tools selected and was by researchers in its activities in order to collect these activities into a systematic and easy by it. For collecting the data, the researcher was two kind of instruments to collect the data. The first instrument is the observation and the second instrument is video recording. 


\section{Data Analysis}

After collecting the data, the researcher obtained the raw data. The data were then analyzed. The data analysis in qualitative research, according to Bogdan and Bilken, is an effort conducted by the researcher in order to organize the data by reducing the data into the organized units, synthesizing the data, finding the pattern, finding the important data, and deciding what to present to the others(Moleong, 2008: 248).

According Sugiyono (2014: 244) data analysis is critical to the qualitative research process. It is to recognize, study, and understand of interrelationship and concept in your data that hypotheses and declaration can be developed and evaluated. In Sugiyono (2014:244) said analysis of any kind involve a way of thinking. It refers to the system examination of something to determine its parts the relation between parts, and the relationship to the whole. Analysis is a search words formation. The researcher classification of speech act. The classification is based on Gorge Yule's theory of words formation process that consist of compounding, derivation, conversion, coinage, borrowing clipping, acronym, blending, back formation (Yule,1996:51). In analyzing the data, the researcher use this table bellow :

To analyze the data, the researcher was recording in the data sheet, the data sheet used by the researcher in the table of speech act there are :

\section{Finding and Disscusion}

In this chapter, the writer wants to the analysis of the data obtained based on the research, conducted on Jule 2016 in MAN 2 Mataram. Based in the research there are tree classification of speech act performed by the Teachers used classification of the speech act in teaching and learning process in classroom in MAN 2 Mataram. The used classification of speech act is locutionary act,ilucationary act and perlocutionary act and This part contains the explanations of the data findings in reference to data analysis. There are three classification of speech act are locutionary act,ilucationary act and perlocutionary act of in this research. Each of them contains several particular functions. All are discussed in this following part.

\subsection{Locutionary Act}

The researcher found 4 Locutionary act are not found in the research. This classification of speech act is special. The performers of these locutionary acts must have the institutional role in specific context to perform these acts Mr. Indra : " $\underline{\text { how }}$ are you today " the moment utterance is being said by the speaker by using the organ of speech act is called locutionary act. Mr. indra want know of condition the students of teaching and learning process today. Mrs. Asry : “ oke Thank you for your attention" the moment utterance is she want to thanks for the students because they are attention of teaching learning process in classroom. Locutionary act are production of utterances, with a particular intended structure, meaning and reference. 


\subsection{Ilocutionary Act}

The researcher found 30 expression of illucotionary act that obtained There are four types of illocutionary acts used by the English teachers at MAN 2 Mataram. They are declaratives, representatives, , expressive,directives, and commissives.

\subsubsection{Declaratives}

The declaratives are not found in the research. This type of illocutionary acts is special. The performers of these illocutionary acts must have the institutional role in specific context to perform these acts appropriately. Also, the declaratives have specific uses in very specific place and events (settings) .

In educational setting, such as in school when teaching-learning process is conducted, this type of illocutionary acts is rarely found. It can be performed, for instance, when the teacher appoints a student as a leader of the class „I appoint you a leader of this class"or when he or she close the class „I declare the today's meeting ends. Nevertheless, there is no class leader election during the research. Also, Teachers" utterance when opening and closing the class does not fulfill IFID of declaratives because in this research the teachers simply use greeting and leave taking function (expressive acts) to open and close the class.

\section{Mrs Asry : "good morning" Mr. indra : "oke thanks for your attention "}

The utterance Mrs. Asry is she want to open the class in teaching learning process also she utterance the use greeting for the firs meeting and than Mr.Indra utterance for the closing the class on teaching learning process he utterance "thanks for your attention".

\subsubsection{Representative}

Representative acts deal with the teachers statement whether it is true or false. Quantitatively, representative acts are in the second rank of the illocutionary act performed by Teachers in MAN 2 Mataram. In classroom conversation, teachers deliver their teaching materials. There are five types of representative functions found in the data. They are stating an opinion, stating a fact, informing, explaining, and agreeing

\subsubsection{Stating an opinion}

This function is used to tell own thoughts, ideas, or opinions rather than facts to the listener. In the classroom,

\subsubsection{Stating a fact}

This illocutionary function is expressed by the speaker to state a fact or a truth which is accepted in general of stating a fact performed by the teachers in classroom communication

$$
\begin{aligned}
& \text { Mr .indra : Saturday and Sunday is weekand } \\
& \text { Yaa,,, what.... } \\
& \text { Ngisep, you know ngisep } \\
& \text { S : hahahaha }
\end{aligned}
$$


The bold expression Mr. Indra utterance the are Saturday and Sunday is weekand is classified as stating a fact.

\subsubsection{Informing}

Informing is expressed by the teacher to give the students information what the students are going to do in relation with the teaching and learning process. There is of informing function performed by teachers of MAN 2 Mataram.

\subsubsection{Explaining}

Explaining is expressed when the speaker wants to make something clear or easy to understand by describing or giving more information about it. In classroom settings, this function is frequently used when teacher explains the teaching-learning materials.

\subsubsection{Agreeing}

Agreeing is illocutionary function which is expressed when the speaker has same opinion with the listener or when the speaker accepts the listener' suggestion or idea. of agreeing functions by the Teacher on teaching-learning process in MAN 2 Mataram.

\subsubsection{Expressives}

Expressive acts deal with the statements of speakers feeling or attitude of particular situation. Based on the research results, expressives are in the third rank of illocutionary act frequency found in classroom communication in teaching-learning process at MAN 2 Mataram.

There are six types of expressive functions found in the data. They are greeting, thanking, complimenting, joking, apologizing, and stating surprise

\subsubsection{Greeting}

Greeting is an expression used to welcome someone. In classroom when a teacher starts the process of teaching and learning in MAN 2 Mataram.

\subsubsection{Thanking}

Thanking is illocutionary function uttered by the speaker when he/she feels gratitude for what the listener does or says.

$\mathrm{T}$ : thank you, assalamu'alaikum warohmatullohiwabarokatuh

$\mathrm{S}$ : walaikum salam warahmatullahiwabarokatuh

the teacher performed thanking expression 'Thank you' as a response of student's willingness to do what teacher has requested.

\subsubsection{Complimenting}

Complimenting is an expression which shows approval, admiration, or respect of what someone does. of complimenting functions performed by the Teachers in teaching-learning process. 


\subsubsection{Joking}

Joking is an expression that is said by the speaker to make the listener laugh. In teaching-learning process, the Teacher generally applies this function to relax the strained situation in the classroom but the reseacher did not found joking by the Teacher in Teaching learning process in MAN 2 Mataram .

\subsubsection{Apologizing}

This illocutionary function is expressed by the speaker for saying sorry for the fault he or she has done. An utterence of this function which is performed by the Teacher but the researcher did not found apologizing by the Teacher in teaching learning process in MAN 2 Mataram.

\subsubsection{Stating surprise}

This function is expressed when the speaker feels shocked because of something or someone, but the researcher did not found of starting surprise by the Teacher in teaching learning process in MAN 2 Mataram.

\subsection{Directives}

Directives are illocutionary acts used by the speaker to get something done. These acts is the highest rank frequency because in classroom discourse, the English teachers use a lot of instructions for the students to do a particular thing, such as asking the students to do the task, to collect the assignment, to open the textbook, or to erase the whiteboard.

\subsubsection{Commanding}

Commanding is the function used to ask or order someone to do something in direct way. but the researcher did not found of commanding by the Teacher on teaching and learning process in MAN 2 Mataram.

\subsubsection{Requesting}

Requesting is an illocutionary function which is used to ask or order someone to do something in indirect or polite way.

\subsubsection{Suggesting}

Suggesting is a directive function performed by the speaker to put forward and idea or plan for the listener to think about.

\subsubsection{Forbidding}

This function is the opposite of commanding function. It is used to order the listener not to do something .

\subsubsection{Questioning}

This illocutionary function is expressed by the speaker in order to get the reply, answer, or information from the listener. 


\subsubsection{Permitting}

Permitting is an illocutionary function expressed by the speaker to allow the listener to do or to say something,

\subsubsection{Encouraging}

Encouraging is an illocutionary function used by the speaker to give the listener support or courage to do something,

\subsubsection{Warning}

This function is uttered by the speaker to tell the listener about danger,

\subsection{Commissives}

Commisives are illocutionary acts dealing with speakers commitment in doing an action in future time. Commissive acts are in the lowest rank of other illocutionary acts found in the research. From the data there are only two types of commissive function performed by English teachers at MAN 2 Mataram. They are promising and threatening. by Mrs.Asry utterence on teaching learning process.

\subsubsection{Promising}

Promising is a function used by the speaker to tell the listener that the speaker will definitely do or not to do something. By Mrs.Asry utteren on teaching learning process

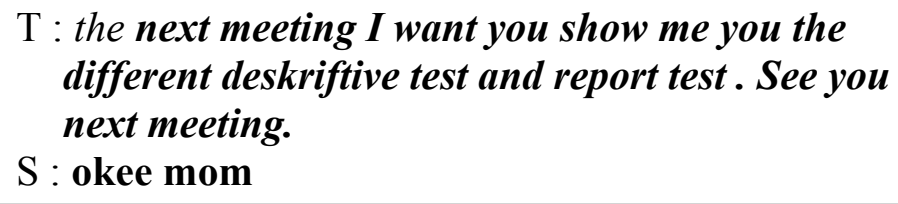

The bold expression conveys a promising function that the teacher would give another example of descriptive and report test. But the school bell rang. That dialogue when she It made the Teacher finished the class with the unfinished explanation. As a result, he committed that he would provide another explanation in the next meeting if the students needed. The use of future marker "will ${ }^{\text {e }}$ also indicates the promising function.

\subsubsection{Threatening}

Using this function, the speaker will cause trouble to the listener if the speaker does not get what he or she wants, but the researcher did not found of thereatening by the Teacher utterence on teaching and learning process in MAN 2 Mataram.

The bold expression conveys a promising function that the teacher would give another example of descriptive and report test. But the school bell rang. That dialogue when she It made the Teacher finished the class with the unfinished explanation. As a result, he committed that he would provide another explanation in the next meeting if the students needed. The use of future marker „want” also indicates the promising function 


\subsection{Perlocutionary Act}

The researcher found 8 expression of Perlocutionary act that obtained word from under expression,From the data there are only two types of pelocutionary act are dirct speech act and indirect speech act by the Teachers at MAN 2 Mataram.

\subsubsection{Direct Speech Acts}

In direct speech act there is a direct relationship between its grammatical structure and its communicative function. For instance, an affirmative sentence is used to give a statement; an interrogative sentence to ask a question; an imperative sentence to give an order

By Mr. indra utterence :

\section{T : You always get up every morning? $\mathrm{S}:$ of COURSE}

In the above utterance performed by Mr.indra and the function are some. $\mathrm{T}$ as a speaker produces a question to $\mathrm{S}$. the question uses interrorgative with question word you always " as well as the question mark at the end of it. The function of that uterence is to question or ask for imformation, viewed from $\mathrm{S}$ " reply. In other way, the speaker expects an answer from the listener. Both the mood and the fuction of T" utterences are same.

\subsubsection{Indirect Speech Acts}

Indirect speech act there is no direct relationship between its grammatical structure and its communicative function. For instance, an introgative is not only used to question or to aks for an answer from the listener, but it can also convey a request or warning. but the researcher did not found of indirect speech act by the Teacher utterence on teaching and learning process in MAN 2 Mataram.

\section{Bibliography}

Anwar, Saiful. 2012. A Pragmatic Analysis on Directive Utterances Used in Donald Duck Comics Manuscript. Unpublished Research Paper. Surakarta: Muhammadiyah University of Surakarta.

Cutting, Joan. 2002. Pragmatics and Discourse: A Resource Book for Students. London and New York: Routledge.

Searle, John R. 1979. Expressing and Meaning: Studies in the Theory of Speech Acts. Cambridge: Cambridge University Press

Bahtiar, Rindang. 2006. A Pragmatic Analysis on the Directive Utterances in theEnglish Translation of Tradition of Bukhari. Unpublished Research Paper. Surakarta: Muhammadiyah University of Surakarta.

Arikunto, S. 2010. Prosedur Penelitian Suatu Pendekatan Praktik. Jakarta: PT Rineka Cipta.

Brown and Levinson. 1987.Politeness: Some Universal in Language Usage. New 
Dwi Purnomo, Maslathief. 2012. Diktat of Semantics In linguistics. Medan. Edinburgh: Edinburgh University Press.

Frank, Marcella. 1972. Modern English: A Practical Reference Guide. London:

Griffiths. Patrick. 2006. An Introduction to English Semantics and Pragmatics.

Krisnawati, Ekaning. 2011. "Pragmatic Competence in the Spoken EnglishClassroom.” In Conaplin Journal, Vol. I/No.1, pp. 104-111. Retrieved from journal.upi.edu/conaplin/view/625/pragmatic-competence-in-thespokenenglish-classroom.html.

Hamdan, HestiSuhartini. 2005. A Pragmatics Analysis on Directive Utterances Used in John Grisham's the Runaway Jury. Unpublished Reasearch Paper. Surakarta: Muhammadiyah University of Surakarta.

Kreidler, W. Charles. 2002. Introducing Semantic English. London : the Taylor and Francis e-library. Pretince-Hall. York: Cambrige University Press.

Arikunto, Suharsimi. 2006. Prosedur Penelitian: Suatu Pendekatan Praktek. Jakarta: Rineka Cipta

Sugiyono. 2014. Metode Penelitian Pendidikan. Bandung: Alfabeta

Yule, George. 1996. Pragmatics. Oxford: Oxford University Press. 